\title{
Effect of recombinant human erythropoietin on anaemia and disease activity in patients with rheumatoid arthritis and anaemia of chronic disease: a randomised placebo controlled double blind 52 weeks clinical trial
}

\author{
H R M Peeters, M Jongen-Lavrencic, G Vreugdenhil, A J G Swaak
}

\begin{abstract}
Objective-To study whether recombinant human erythropoietin (r-hu-Epo) improves anaemia and reduces disease activity in patients with rheumatoid arthritis and anaemia of chronic disease (ACD).

Methods-A 52 week placebo controlled randomised double blind trial with r-hu-Epo was performed in 70 patients with active rheumatoid arthritis and ACD. Thirty four patients were treated with $240 \mathrm{U} \mathrm{kg}^{-1}$ r-hu-Epo subcutaneously, initially three doses weekly, while 36 patients received placebo.
\end{abstract}

Results-A significant increase of haemoglobin from a median of 112 to $135 \mathrm{~g} \mathrm{litre}^{-1}$ occurred in the Epo group within six weeks and could be sustained with reduced doses (median $240 \mathrm{U} \mathrm{kg}^{-1}$ once weekly). Sustained benefit compared to placebo was also apparent by six weeks for disease activity, as indicated by the Paulus $20 \%$ response rate. Of patients in the Epo group, 32\% eventually showed a Paulus $20 \%$ response, compared to $8 \%$ of the placebo group $(P=0.016)$. Significant differences in favour of the Epo group were also observed in the secondary disease activity measures Ritchie index, number of swollen joints, pain score, ESR, and patients' global assessment of disease activity. $C$ reactive protein concentrations did not change significantly.

Conclusions-Treatment of ACD in rheumatoid arthritis with $\mathbf{r}-\mathrm{hu}-\mathrm{Epo}$ is effective in restoring normal haemoglobin levels and also exerts a beneficial effect on disease activity.

(Ann Rheum Dis 1996;55:739-744)

Anaemia often occurs in patients with rheumatoid arthritis. ${ }^{1}$ Anaemia of chronic disease (ACD) is the most important cause of anaemia in this condition. ${ }^{2-4}$ It is characterised by low serum iron concentrations despite normal or increased body iron stores. ${ }^{5-7}$ The pathogenesis of ACD in rheumatoid arthritis is multifactorial. ${ }^{3}$ Iron retention by the mononuclear phagocyte system (MPS) and impaired iron transport to the erythroblast have been described. ${ }^{8}$ Suppression of erythropoiesis by inflammatory cytokines, such as interleukin-1
(IL-1), tumour necrosis factor $\alpha$ (TNF- $\alpha$ ), and $\gamma$ interferon, has been shown in vitro.9-12 In addition, evidence has been provided for a relatively impaired production of erythropoietin in response to anaemia. Serum erythropoietin concentrations in ACD are lower than in other anaemic conditions ${ }^{13-15}$ and IL-1 and TNF- $\alpha$ have been shown to suppress hypoxia related erythropoietin production by HepG2 and Hep3b cell line in vitro. ${ }^{16}{ }^{17}$

In a number of studies treatment with r-huEpo resulted in improvement of ACD in rheumatoid arthritis patients. ${ }^{18-25}$ However, higher doses of human recombinant erythropoietin (r-hu-Epo) were required to maintain the haematological response than in renal disease. ${ }^{26}$ In one open pilot study with r-hu-Epo, a decrease in both pain score and swollen and painful joint count was observed, indicating possible beneficial effects on disease activity as well. ${ }^{27}$ In the five other open and two controlled clinical studies only slight, or no, effects on disease activity were observed, although an improvement in general wellbeing was reported in several instances. ${ }^{21-24}$ These studies were of short duration (2-24 weeks) and involved only a limited number of patients (2-20). We conducted a 52 week placebo controlled randomised double blind trial with r-hu-Epo as adjuvant treatment in patients with active rheumatoid arthritis and ACD to investigate the effects of long term treatment with r-hu-Epo on haematological indices as well as on clinical and serological measures of disease activity.

\section{Methods}

PATIENTS

Patients aged 18 years or older were eligible if they met the revised American College of Rheumatology (ACR) criteria for rheumatoid arthritis ${ }^{28}$ and were classified in functional class I, II, or III. ${ }^{29}$ Active disease was required, defined as a minimum of nine swollen joints and a Ritchie score of 9. Treatment with the following disease modifying antirheumatic drugs was allowed, provided the dose was stable for three months before the start of the trial: oral gold, hydroxychloroquine, D-penicillamine, sulphasalazine, and methotrexate. Parenteral gold salts were allowed if the dose was stable for at least six months. Patients receiving azathioprine, cyclophosphamide, or cyclosporin were excluded. Treatment with corticosteroids, equivalent to an average 
maximum daily dosage of $10 \mathrm{mg}$ prednisone, was allowed if dosage had not been changed the last month before entry to the trial.

Anaemia of chronic disease for a minimum duration of three months had to be present in all patients. Haemoglobin concentrations below $117 \mathrm{~g}$ litre $^{-1}$ (for both males and females) were required without signs of vitamin and iron deficiency, blood loss, haemolysis, or other haematological disorder. Body iron stores were assessed preferably by iron staining of bone marrow smears. A semiquantitative scale was used: $0=$ no stainable iron; $0-1=$ minimal to very small amount; $2=$ slight small and patchy content; 3 or more $=$ increased stainable iron. Patients with a stainable iron content of 2 or more were considered not to be iron deficient. ${ }^{30}$ When patients did not agree with bone marrow aspiration, serum ferritin levels should be above $50 \mathrm{mg}$ litre ${ }^{-1}$ and serum transferrin levels below $50 \mathrm{mmol}$ litre $^{-1}$. $^{3}$

Further exclusion criteria were: history of thromboembolic events or epileptic fits, uncontrolled hypertension, and clinically relevant impairment of kidney or liver function.

All patients gave their informed consent for the trial, which was approved by the institutional ethics committee.

\section{TREATMENT}

The study was a 52 week randomised double blinded placebo controlled parallel clinical study. Disease activity measures were assessed by the first observer (RP), who remained blinded for treatment schedules and laboratory results. Randomisation of the patients, control of adverse events and laboratory results, and administration of the study medication was done by a second independent observer (MJ). The treatment group received r-hu-Epo (Recormon, Boehringer Mannheim) at a dose of $240 \mathrm{U} \mathrm{kg}^{-1}$ subcutaneously (sc), initially three times a week. The aim of the treatment was a normal $\mathrm{Hb}$ level (female $>117$; male > $\left.136 \mathrm{~g} \mathrm{litre}^{-1}\right)$ and the dose was adjusted accordingly by changing the frequency of administration. The placebo group received a visually similar placebo. After randomisation, patients in the placebo group were matched with patients in the treatment group and followed their treatment regime with respect to frequency of administration. Oral iron supplementation was given if serum ferritin fell below $50 \mathrm{mg}$ litre $^{-1}$, and was discontinued upon iron repletion. Adjustment of the dose of disease modifying antirheumatic drugs or prednisone, as well as local measures, particularly intra-articular corticosteroid injections, was not allowed during the study.

ASSESSMENTS

Patients were evaluated every two weeks for three months and monthly afterwards until week 52 .

\section{Primary assessments}

Effects of treatment of anaemia were evaluated using haemoglobin $(\mathrm{Hb})$. As primary disease activity measure the clinical response in individual patients was analysed using a modified Paulus index. ${ }^{31}$ According to this composite index, patients are considered to show a significant clinical response if at least four out of six variables [Ritchie index, number of swollen joints, duration of morning stiffness, both patients' and observers' assessment of disease activity, and erythrocyte sedimentation rate (ESR)] improve. As our secondary disease activity measures did not include an observer's global assessment of disease activity, the Paulus response was evaluated using the other five variables. Patients had to show simultaneous improvement in four of these five variables in order to fulfil the criteria for a $20 \%$ Paulus response. Improvement was defined by a $20 \%$ decrease in the continuous variables and a $40 \%$ decrease in the patients global assessment of disease activity (1-10 scale) (or $20 \%$ in case of baseline value below 4.0).

\section{Secondary assessments}

As secondary evaluation criteria a core set of single measures of disease activity endorsed by the $\mathrm{ACR}^{32}$ was used. Besides the Ritchie index, the number of swollen joints, patients' global assessment, and Westergren ESR, this includes a pain score (1-10) and $C$ reactive protein concentrations. Serum ferritin was assessed on every visit as the primary marker for iron status and as a guideline for iron suppletion.

\section{STATISTICAL PROCEDURES}

Data from the patient files were transferred to software packages (SPSS 5.01 and Egret) for statistical analysis. All variables were checked for their suitability for standard statistical analysis. In case of non-parametric distribution a transformation towards normality was tried. At baseline, groups were compared using Student's $t$ test, the Mann-Whitney test, and the $\chi^{2}$ test where appropriate. The repeated measurements of continuous outcome variables in the two groups were analysed by analysis of variance for repeated measurements (MANOVA) using weeks 0 (baseline), 6, 12, 24,36, and 52 as time points. The overall effect of treatment was tested for significance using the $F$ test on the interaction between the two patient groups and the repeated measurements factor time. In case of significance, differences between the groups at individual time points were investigated with Bonferroni correction for multiple testing. Overall treatment effects on the Paulus $20 \%$ response rate were evaluated using logistic regression with random effects. Groups were compared at individual points of follow up using Fischer's exact tests.

Analysis was done on the basis of intention to treat as well as on completers. Both methods led to the same results except for slight differences in the Paulus $20 \%$ response rate. Results of the intention to treat analysis are shown and end point differences in Paulus response described separately.

\section{Results}

PATIENTS

Seventy patients were enrolled in the study, 34 receiving r-hu-Epo (Epo group) and 36 receiv- 
ing placebo (placebo group). No significant differences in demographic and disease characteristics between the treatment groups were found (table 1). Baseline haemoglobin concentrations were the same in the two groups (table 1). In 51 patients the diagnosis of anaemia of chronic disease was made by iron staining of bone marrow smears, while in the remaining 19 patients iron deficiency was ruled out using serum ferritin and transferrin levels. Fifty eight patients completed the study. Five patients withdrew from the Epo group (after a median period of 24 weeks), in three cases because of high disease activity and in two because of poor compliance. Seven patients withdrew from the placebo group (after a median of 16 weeks), five for reasons of high disease activity and two because of poor compliance. Injections of r-hu-Epo were tolerated well. No local reactions or other serious side effects were observed. None of the patients, including those patients already being treated with antihypertensive drugs before the start of the trial, showed a significant rise in blood pressure. No thromboembolic complications were observed.

PRIMARY ASSESSMENTS

The Epo group showed significantly higher haemoglobin concentrations during treatment (figure, panel A). A statistically significant increase in $\mathrm{Hb}$ occurred within six weeks and could be sustained during entire follow up period. At the end of follow up the Epo group showed a median $\mathrm{Hb}$ of 134 (range 110 to 158 $\left.\mathrm{g} \mathrm{litre}^{-1}\right)$, compared to $112\left(86-128 \mathrm{~g} \mathrm{litre}^{-1}\right)$ in the placebo group. After a median of six weeks (range 2 to 24) the dose of r-hu-Epo could be decreased in $90 \%$ of responders to an eventual median of one injection (range 0.5 to 2) of 240 $\mathrm{U} \mathrm{kg}^{-1}$ weekly at the end of follow up. Of 34 patients in the Epo group, $32(94 \%)$ achieved a normal $\mathrm{Hb}$ during follow up, compared to eight out of $36(22 \%)$ of placebo treated patients. The first of the two non-responders initially showed a rise in $\mathrm{Hb}$ from $98 \mathrm{~g} \mathrm{litre}^{-1}$ at baseline to $118 \mathrm{~g}$ litre $^{-1}$ at week 8 , but consequently fell back to $98 \mathrm{~g}$ litre ${ }^{-1}$ again without responding to an increase of the weekly dosage to four times $240 \mathrm{U} \mathrm{kg}^{-1}$. The other

Table 1 Baseline characteristics of the two treatment groups. Data are presented as median (5th to 95th centile) or number (percentage).

\begin{tabular}{|c|c|c|}
\hline \multirow{5}{*}{$\begin{array}{l}\text { Variable } \\
\text { No of patients } \\
\text { Female }(\%) \\
\text { Age (years) } \\
\text { Haemoglobin }\left(\mathrm{g} \mathrm{l}^{-1}\right) \text { : All }\end{array}$} & Epo & Placebo \\
\hline & & 36 \\
\hline & $27(79 \%)$ & $31(86 \%)$ \\
\hline & $56(23 / 79)$ & $58(39 / 75)$ \\
\hline & $\begin{array}{l}111 \\
(93-116)\end{array}$ & $\begin{array}{l}113 \\
(101-106)\end{array}$ \\
\hline Female & 109 & 113 \\
\hline & $(93-116)$ & $(101-106)$ \\
\hline Male & $\begin{array}{l}114 \\
(107-116)\end{array}$ & $\begin{array}{l}114 \\
(113-116)\end{array}$ \\
\hline Disease duration (years) & $3.5(0.3 / 21)$ & $4.7(0.3 / 32)$ \\
\hline Positive rheumatoid factor (\%) & $18(53 \%)$ & $21(58 \%)$ \\
\hline Erosive joint damage (\%) & $29(85 \%)$ & $28(78 \%)$ \\
\hline $\begin{array}{l}\text { No of patients using DMARD } \\
(\%)\end{array}$ & $23(68 \%)$ & $27(75 \%)$ \\
\hline $\begin{array}{l}\text { No of patients using } \\
\text { methotrexate }\end{array}$ & $3(9 \%)$ & $4(11 \%)$ \\
\hline $\begin{array}{l}\text { No of patients using prednisone } \\
(\%)\end{array}$ & $3(9 \%)$ & $6(17 \%)$ \\
\hline
\end{tabular}

Epo, erythropoietin; DMARD, disease modifying antirheumatic drugs non-responder showed no response of $\mathrm{Hb}$ at all, despite increasing dosages of rh-h-Epo. In both patients no other causes of anaemia besides ACD were diagnosed. The first patient used sulphasalazine, while the second patient was treated with hydroxychloroquine.

A Paulus $20 \%$ response was observed significantly more often in patients of the Epo group, compared to patients of the placebo group (figure, panel B). This effect occurred within six weeks of treatment and could be sustained throughout follow up. Of all patients treated with rhu-Epo, $32 \%$ achieved a Paulus $20 \%$ response at the end of their follow up compared to $8 \%$ in placebo group. For those patients completing 52 weeks these percentages were respectively $38 \%$ and $8 \%$.

\section{SECONDARY ASSESSMENTS}

Compared to the placebo group, significant improvements were observed in Ritchie articular index, the number of swollen joints, patients' global assessment of disease activity, and pain score in the Epo group (table 2). The changes within time in these variables were similar to those in the primary outcome measures, with sustained improvement in the Epo group reached within six weeks (Ritchie index and swollen joint count) or 12 weeks (patient assessment and pain). ESR showed a rapid decline in the Epo group, reaching its lowest level during weeks 6-12, and then increased again but remained significantly lower than in the placebo group (table 2). C reactive protein concentrations levels did not change significantly in either of the treatment groups (table 2).

An overall difference in ferritin concentrations between the two treatment groups was observed (table 2). Ferritin showed a fast and steep decline in the Epo group during the first phase of the trial. Iron supplementation proved necessary in $88 \%$ of Epo treated patients, predominantly in the first period of r-hu-Epo treatment (after a median of four weeks). In $77 \%$ of these patients it was later possible to discontinue iron supplementation. The duration of treatment with iron supplements was a median of eight weeks. During the later stage of the trial, serum ferritin concentrations remained significantly lower in the Epo group compared to baseline or to the placebo group.

\section{Discussion}

Our results suggest that in patients with active rheumatoid arthritis and well classified ACD, $\mathrm{r}$-hu-Epo is effective in restoring normal $\mathrm{Hb}$ concentrations as well as reducing rheumatic disease activity. Sustained benefit compared to placebo was apparent by six weeks for both $\mathrm{Hb}$ concentrations and the primary measures of disease activity. Normalisation of $\mathrm{Hb}$ was achieved in $94 \%$ of treated patients. At the end of follow up $32 \%$ of the patients in the Epo group fulfilled the criteria for a Paulus $20 \%$ response, compared to $8 \%$ of the placebo treated patients. Significant differences in favour of the treatment group were also observed in the secondary outcome measures: Ritchie index, number of swollen joints, pain 


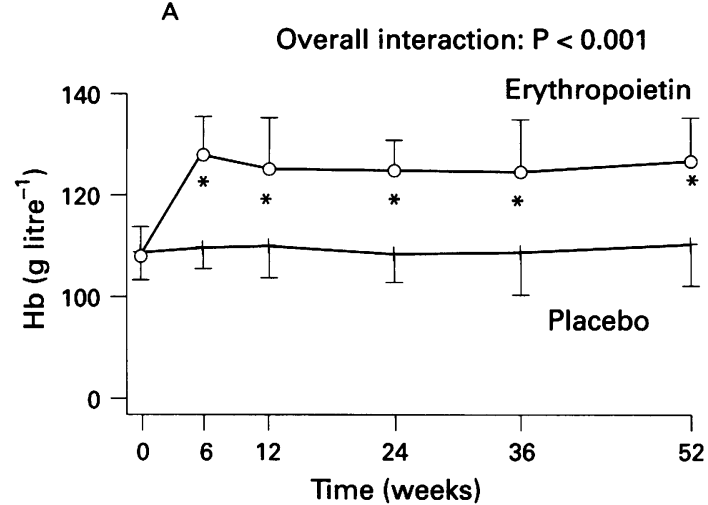

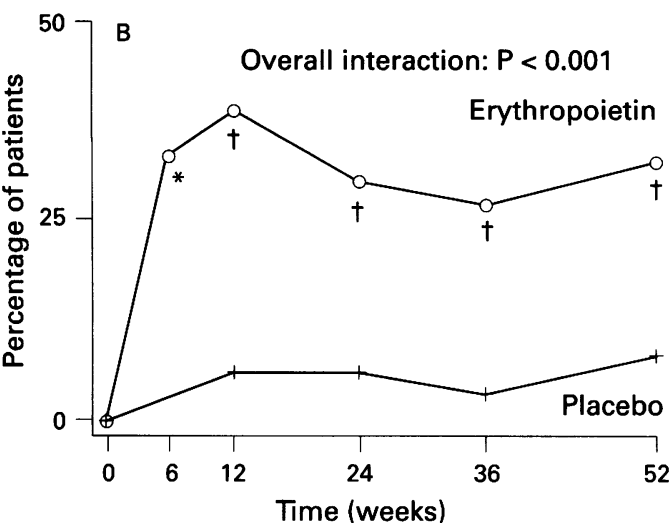

Time (weeks)

Primary outcome measures. (A): median $\mathrm{Hb}$ (interquartile range) in the two treatment groups. (B): percentage of patients fulfilling the criteria for a Paulus $20 \%$ response. Statistical analysis: $P$ values for overall interaction between groups and time calculated with analysis of variance for repeated measurements (MANOVA) for Hb, and logistic regression with random effects for Paulus $20 \%$ response. Between group comparisons at individual time points: ${ }^{\star} P<0.001,+P<0.01$.

score, ESR, and patients' global assessment of disease activity. $\mathrm{C}$ reactive protein concentrations did not change significantly. Normal levels of $\mathrm{Hb}$ could be sustained with reduced dosage of r-hu-Epo in most patients, and concomitant iron suppletion proved only temporarily necessary during the induction of the haematological response.

The observed response of $\mathrm{Hb}$ during r-hu-Epo treatment was comparable with previous clinical studies with r-hu-Epo in rheumatoid arthritis and ACD. ${ }^{202}{ }^{23-25} \mathrm{As}$ in the present study, dosage of r-hu-Epo could be reduced in responders, although the maintenance dosage of $r$-hu-Epo varied considerably between patients. ${ }^{20}{ }^{23}{ }^{24}$ Although an initially higher dosage of r-hu-Epo was used in the present study than in previous clinical trials, the eventual maintenance dosage did not differ significantly. ${ }^{22-24}$

A modified Paulus index was used as a primary measure of disease activity. The observed frequency of a Paulus $20 \%$ response in $8 \%$ of all controls is comparable with the observed responses in $3-12 \%$ of control patients in previous trials. ${ }^{31}$ Significant bias due to the modification of the Paulus criterium seems unlikely. The occurrence of a Paulus $20 \%$ response in $32 \%$ of all $r-h u-E p o$ treated patients is comparable with results of controlled studies with several of the now widely used disease modifying antirheumatic drugs. ${ }^{31}$ The fall of ESR in the Epo treated patients may reflect correction of anaemia. However, one cannot exclude the possibility that the changes in ESR are partially related to changes in disease activity as well. In the later stage of the trial a rise in ESR was observed without significant concomitant changes in $\mathrm{Hb}$ levels, suggesting the possible role of other factors involved in the ESR. The other secondary disease activity measures used in the Paulus index are not clearly influenced by correction of anaemia and all show significant improvement in the Epo treated patients. Therefore the differences in 20\% Paulus response between the two treatment groups should be considered to reflect the

Table 2 Course of secondary disease activity measures and serum ferritin

\begin{tabular}{|c|c|c|c|c|c|c|c|c|}
\hline \multirow{2}{*}{ Variable } & \multirow{2}{*}{ Group } & \multicolumn{6}{|l|}{ Follow up } & \multirow{2}{*}{ Overall } \\
\hline & & Baseline & Week 6 & Week 12 & Week 24 & Week 36 & Week 52 & \\
\hline \multirow{3}{*}{$\begin{array}{l}\text { Ritchie articular index } \\
(0-81)\end{array}$} & Epo & 26 (10 to 43$)$ & $19(4$ to 37$)$ & 17 (4 to 37$)$ & 15 (2 to 35$)$ & 14 (2 to 37$)$ & 15 (3 to 32$)$ & \multirow[t]{3}{*}{$P=0.002$} \\
\hline & Placebo & 31 (17 to 44$)$ & $30(10$ to 43$)$ & $29(10$ to 54$)$ & 28 (9 to 48$)$ & 26 (6 to 48$)$ & 26 (3 to 48$)$ & \\
\hline & $95 \% \mathrm{CI}$ & & 1 to 4 & 2 to 5 - & 1 to $4 \dagger$ & 1 to $4^{\star}$ & 1 to $4^{\star}$ & \\
\hline \multirow{2}{*}{$\begin{array}{l}\text { Swollen joints } \\
\text { (number 0-52) }\end{array}$} & Epo & 28 (13 to 34$)$ & $18(7$ to 31$)$ & 19 (5 to 33$)$ & $17(5$ to 32$)$ & $17(5$ to 35$)$ & $19(5$ to 34$)$ & \multirow[t]{2}{*}{$P=0.003$} \\
\hline & $\begin{array}{l}\text { Placebo } \\
95 \% \text { CI }\end{array}$ & 29 (17 to 37$)$ & $\begin{array}{l}28(17 \text { to } 37) \\
1 \text { to } 4 t\end{array}$ & $\begin{array}{l}26(15 \text { to } 40) \\
1 \text { to } 3 \dagger\end{array}$ & $\begin{array}{l}26(13 \text { to } 38) \\
1 \text { to } 4 \dagger\end{array}$ & $\begin{array}{l}27(14 \text { to } 39) \\
1 \text { to } 3 \dagger\end{array}$ & $\begin{array}{l}27(15 \text { to } 39) \\
1 \text { to } 3 \dagger\end{array}$ & \\
\hline $\begin{array}{l}\text { Patients' global } \\
\text { assessment }\end{array}$ & Epo & $4.4(2.5$ to 6.0$)$ & $3.8(1.0$ to 6.0$)$ & $\begin{array}{l}3.5(1.5 \text { to } \\
5.5)\end{array}$ & $3.7(1.5$ to 6.0$)$ & $4.0(1.5$ to 6.0$)$ & $3.5(1.0$ to 6.0$)$ & $P=0.027$ \\
\hline \multirow[t]{2}{*}{ (VAS score $0-10$ ) } & Placebo & $4.3(2.0$ to 7.0$)$ & $4.2(1.0$ to 7.5$)$ & $\begin{array}{l}4.0(1.0 \text { to } \\
7.0)\end{array}$ & $4.5(1.0$ to 7.0$)$ & 4.7 (1.0 to 7.5$)$ & 4.5 (2.0 to 7.5$)$ & \\
\hline & $95 \% \mathrm{CI}$ & & -0.1 to 0.6 & 0.0 to 0.6 & 0.1 to $0.7^{\star}$ & 0.0 to 0.6 & 0.2 to $0.8^{\star}$ & \multirow{3}{*}{$P=0.002$} \\
\hline Pain & Epo & $5.0(2.0$ to 8.0$)$ & $4.5(1.0$ to 7.5$)$ & $\begin{array}{l}4.2(1.0 \text { to } \\
7.0)\end{array}$ & $4.0(0.5$ to 9.0$)$ & $4.0(1.0$ to 8.5$)$ & $3.5(2.0$ to 7.0$)$ & \\
\hline \multirow[t]{2}{*}{ (VAS score $0-10$ ) } & Placebo & $5.0(2.5$ to 8.0$)$ & $5.1(1.5$ to 9.0$)$ & $\begin{array}{l}5.2(1.5 \text { to } \\
9.5)\end{array}$ & $5.8(2.0$ to 9.8$)$ & 5.8 (2.0 to 9.8$)$ & $5.6(2.0$ to 9.8$)$ & \\
\hline & $95 \% \mathrm{CI}$ & & -0.1 to 0.7 & 0.1 to $0.9^{\star}$ & 0.3 to $1.2 \dagger$ & 0.3 to $1.2 \dagger$ & 0.4 to 1.29 & \multirow[b]{2}{*}{$P=0.035$} \\
\hline $\begin{array}{l}\text { ESR } \\
\left(\mathrm{mm} \mathrm{h}^{-1}\right)\end{array}$ & $\begin{array}{l}\text { Epo } \\
\text { Placebo } \\
95 \% \text { CI }\end{array}$ & $\begin{array}{l}56(25 \text { to } 110) \\
44(15 \text { to } 110)\end{array}$ & $\begin{array}{l}23(6 \text { to } 102) \\
45(17 \text { to } 110) \\
10 \text { to } 199\end{array}$ & $\begin{array}{l}28(9 \text { to } 94) \\
45(13 \text { to } 110) \\
9 \text { to } 19 \text { - }\end{array}$ & $\begin{array}{l}39(14 \text { to } 107) \\
52(12 \text { to } 110) \\
2 \text { to } 12 \dagger\end{array}$ & $\begin{array}{l}39(11 \text { to } 97) \\
50(12 \text { to } 110) \\
4 \text { to } 13 t\end{array}$ & $\begin{array}{l}35(9 \text { to } 97) \\
48(11 \text { to } 110) \\
5 \text { to } 14 \text { 1 }\end{array}$ & \\
\hline CRP & Epo & 28 (2 to 101$)$ & 23 (2 to 91 ) & $30(2$ to 115$)$ & 31 (2 to 123) & $29(2$ to 144$)$ & 37 (3 to 113 ) & $P=0.122$ \\
\hline$\left(\mathrm{mg} \mathrm{l}^{-1}\right)$ & $\begin{array}{l}\text { Placebo } \\
95 \% \text { CI }\end{array}$ & $19(2$ to 66$)$ & $\begin{array}{l}23(2 \text { to } 84) \\
-4 \text { to } 8\end{array}$ & $\begin{array}{l}22(2 \text { to } 91) \\
-5 \text { to } 7\end{array}$ & $\begin{array}{l}11(2 \text { to } 93) \\
-12 \text { to } 1\end{array}$ & $\begin{array}{l}14(2 \text { to } 96) \\
-8 \text { to } 4\end{array}$ & $\begin{array}{l}21(2 \text { to } 94) \\
-4 \text { to } 8\end{array}$ & \\
\hline $\begin{array}{l}\text { Serum ferritin } \\
\left(\mu \mathrm{g} \mathrm{I}^{-1}\right)\end{array}$ & $\begin{array}{l}\text { Epo } \\
\text { Placebo } \\
95 \% \text { CI }\end{array}$ & $\begin{array}{l}93(28 \text { to } 402) \\
79(25 \text { to } 241)\end{array}$ & $\begin{array}{l}29(10 \text { to } 215) \\
67(22 \text { to } 230) \\
25 \text { to } 559\end{array}$ & $\begin{array}{l}52(10 \text { to } 221) \\
68(21 \text { to } 148) \\
9 \text { to } 39 t\end{array}$ & $\begin{array}{l}75(13 \text { to } 133) \\
67(23 \text { to } 191) \\
-13 \text { to } 28\end{array}$ & $\begin{array}{l}67(13 \text { to } 227) \\
70(57) \\
-3 \text { to } 28\end{array}$ & $\begin{array}{l}51(14 \text { to } 213) \\
67(24 \text { to } 181) \\
4 \text { to } 35^{\star}\end{array}$ & $P<0.001$ \\
\hline
\end{tabular}

Data presented as median (5th to 95th centile). No significant differences between groups were found at baseline. CI, confidence interval. Statistics: Overall effect of treatment ( $P$ value on the interaction between groups and time) and between-group comparison at individual time points $\left(95 \% \mathrm{CI}\right.$ and $\mathrm{P}$ values : ${ }^{\star} \mathrm{P}<0.05$, $+\mathrm{P}$ $<0.01$, ๆ $P<0.001$ ) calculated with analysis of variance for repeated measurements (MANOVA). 
improvement of disease activity in Epo treated patients. It is not clear why $\mathrm{C}$ reactive protein concentrations did not change despite the observed clinical response. However, the relation between disease activity and the acute phase response is not fully understood yet. A subset of rheumatoid arthritis patients has been described in whom disease progresses clinically without an increase in $\mathrm{C}$ reactive protein and ESR. ${ }^{33}$ Non-steroidal antiinflammatory drugs fail to lower $\mathrm{C}$ reactive protein, although they reduce inflammatory activity. ${ }^{34}$ Recently oral corticosteroids were reported to decrease rheumatoid disease activity and the progression of joint destruction without effect on acute phase response. ${ }^{35}$ Independent development of erosions, clinical symptoms, and the acute phase response was observed, though the separate control mechanisms have not yet been identified. ${ }^{35}$ One should consider the possibility that r-hu-Epo may exert beneficial effects on disease activity without decreasing C reactive protein levels. However, the mechanisms for this action still remain unclear.

Comparison of the observed clinical effects with previous trials with r-hu-Epo in rheumatoid arthritis is more difficult, since a similar measure of disease activity was not used. Two studies were placebo controlled double blind studies, ${ }^{20}{ }^{24}$ but comprised considerably fewer patients ( 17 and 20 respectively). Pincus and coworkers measured pain score and a health assessment questionnaire (HAQ) and found no differences between r-hu-Epo treated patients and controls. Patients receiving disease modifying antirheumatic drugs were excluded and r-hu-Epo was given intravenously (three times a week at $50-150 \mathrm{U} \mathrm{kg}^{-1}$ ). ${ }^{20}$ Murphy et al evaluated pain score, Ritchie index, duration of morning stiffness, HAQ score, and $C$ reactive protein and observed a trend towards improvement in pain score and $\mathrm{C}$ reactive protein but not the other variables. ${ }^{24}$

Three of the open label studies examined more than 10 patients. Swaak et al described a statistically significant reduction in number of swollen joint, Ritchie index, pain score, and duration of morning stiffness in 10 patients treated for nine weeks. ${ }^{27}$ Güdbjörnson et al required patients to have active disease and observed a reduction of the Ritchie index in seven of 10 patients within six weeks, although the mean Ritchie index of the entire group did not improve significantly. ${ }^{22}$ Functional capacity, duration of morning stiffness, and joint pain did not change. Pettersson et al evaluated joint pain, morning stiffness and a joint score in 11 patients without finding any effect. ${ }^{23}$ However, an improvement in general wellbeing was described by most workers even in the absence of clinical improvement. ${ }^{21-24}$ As in the present study, a decrease of ESR, but not of $\mathrm{C}_{20}$ reactive protein was observed in most studies. ${ }_{22}{ }^{23-24}$ Thus indications for a possible effect of r-hu-Epo on disease activity were found in previous studies. A similar improvement of disease activity-as observed in the present study-has not been described before. Considerable differences in number and selection of patients, dosage of $r$-hu-Epo, duration of treat- ment, and concomitant iron supplementation, as well as disease activity measures used, could perhaps account for these differences in observed clinical responses to r-hu-Epo.

Several mechanisms can explain the beneficial effects of r-hu-Epo. Treatment with r-hu-Epo increases iron turnover, which is mobilised from storage elsewhere in the body and transferred to the bone marrow to fulfil the enhanced requirements of stimulated erythropoiesis. ${ }^{36}$ Deposition of iron in synovial tissue was found to be increased in rheumatoid arthritis. ${ }^{37}$ This has been associated with persistent joint inflammation in rheumatoid arthritis ${ }^{39}$ since iron catalyses the generation of toxic oxygen radicals, ${ }^{24}$ stimulates DNA synthesis in synovial cells, and has an additive effect on the activity of human cytokines for proliferation of synovial cells. ${ }^{40}$ Iron suppletion has been associated with exacerbation of synovial inflammation in rheumatoid arthritis patients, ${ }^{41}$ whereas iron chelators caused a rapid decrease in body iron storage and an improvement in clinical disease activity. ${ }^{15}{ }^{42}$ In the present study an equally rapid decrease in body iron stores and rheumatic disease activity was observed. Reduction of the iron availability in synovial tissue could account for the observed improvement in disease activity during $\mathrm{r}$-hu-Epo treatment.

In addition to effects on iron deposition, modulating effects of r-hu-Epo on the immune system cannot be ruled out entirely. Erythropoietin has been found to regulate $\operatorname{IgE}$ production in vitro by $T$ cell and monocyte dependent mechanisms. ${ }^{43}$ In renal patients treated with r-huEpo, an improvement in $\mathrm{T}$ cell function has been described. ${ }^{44}$ To what extent these observations are associated with the beneficial clinical effects of r-hu-Epo in rheumatoid arthritis in the present study remains to be established. A randomised study of the effects of rhu-Epo and blood transfusion on both the immune system and clinical disease activity might be helpful in elucidating the way of action of $r$-hu-Epo.

The clinical use of r-hu-Epo may be limited by its expense. Furthermore, one can argue whether ACD should be treated in rheumatoid arthritis patients, as it is usually mild. ${ }^{4}{ }^{5}$ However, ACD is a frequent manifestation in rheumatoid arthritis, ${ }^{1}{ }^{4}$ and in our study treatment of this typically mild anaemia with r-hu-Epo had a beneficial effect. Furthermore, no side effects were observed. This might result in an important improvement of the quality of life of rheumatoid arthritis patients, which is considered to be a major aim of treatment. Therefore further research on the effects of r-hu-Epo on quality of life in relation to its costs-as compared to standard regimens-is required to elucidate the value of r-hu-Epo in the treatment of rheumatoid arthritis and ACD. Other patient groups, like anaemic patients undergoing surgery or anaemic patients starting with slow acting second line drugs, should be studied in this way as well.

In summary, our study is the first randomised placebo controlled long term study with r-huEpo in which effects on 
anaemia as well as on disease activity were studied extensively and adequately in a large number of patients with active rheumatic disease and anaemia of chronic disease. Rapid normalisation of $\mathrm{Hb}$ occurred in the majority of patients. Parallel to the response of $\mathrm{Hb}$, a rapid and sustained improvement in disease activity was observed. The results of this trial suggest that $r$-hu-Epo might serve as a useful addition to the therapeutic armamentarium in rheumatoid arthritis patients with active disease and ACD.

We would like to express our gratitude to Prof F C Breedveld (Department of Rheumatology, University Hospital Leiden, The Netherlands) for critically revising this manuscript, to Boehringer-Mannheim for providing r-hu-Epo (Recormon), to H M Markusse, A C M Romme, and J H L M van Groenendae (Department of Rheumatology, Daniel den Hoed Clinic, Rotterdam) for their help in recruiting the patients and to $L$ Baggerman for his help in processing the laboratory data. This study was made possible by a grant from the Dutch League against Rheumatism ("Het Nationaal Rheuma Fonds").

1 Mowat AG. Hematologic abnormalities in rheumatoid arthritis. Semin Arthitis Rheum 1971;1:383-90.

2 Hansen NE. The anaemia of chronic disorders: a bag of unsolved questions. Scand $\mathcal{F}$ Haematol 1983;31:397-402.

3 Vreugdenhil G, Wognum AW, Van Eijk HG, Swak AJ. Anaemia in rheumatoid arthritis: the role of iron, vitami B12, and folic acid deficiency, and erythropoietin responsiveness. Ann Rheum Dis 1990;49:93-8.

4 Peeters HRM, Jongen-Lavrencic M, Raja AN, Ramdin HS Vreugdenhil G, Breedveld FC, et al. Course and characteristics of anaemia in patients with rheumatoid arthritis of recent onset. Ann Rheum Dis 1996;55:162-8.

5 Cartwright GE, Lee GR. The anaemia of chronic disorders. Br 7 Haematol 1971;21:147-52.

6 Krantz SB. Pathogenesis and treatment of the anemia of chronic disease. Am $f$ Med Sci 1994;307:353-9.

7 Smith RJ, Davis P, Thomson ABR, Wadsworth LD, Fackre $P$. Serum ferritin levels in the anaemia of rheumatoid arthritis. $f$ Rheumatol 1977;4:389-92.

8 Roester HP. Iron metabolism in inflammation and malig nant disease. In: Jacobs A, Worwood $\mathrm{M}$, eds. Iron in biochemistry and medicine II. London: Academic Press, 1980:605-40.

9 Maury CJP, Anderson LC, Teppo AM, Partanen S, Juvonen E. Mechanism of the anaemia in rheumatoid arthritis: demonstration of raised interleukin lbeta concentrations in anaemic patients and of interleukin 1 mediated suppression of normal erythropoiesis and proliferation of human erythroleukemia (HEL). Ann Rheum Dis 1988, 47:972-87.

10 Roodman GD, Bird A, Hutzer D, Montgomery W. Tumo necrosis factor-alpha and haematopoietic progenitors K562, HL60 and HEL cells. Exp Hematol 1987;15:92835 .

11 Means RT, Krantz SB. Inhibition of human erythroid colony-forming units by gamma interferon can be corrected by recombinant human erythropoietin [see comments]. Blood 1991;78:2564-7.

12 Jongen-Lavrencic M, Peeters HRM, Wognum AW, Vreugdenhil G, Swaak AJG. Erythropoietin receptor expression on bone marrow cells from rheumatoid arthritis patients with anaemia of chronic disease and control patients. Clin Rheumatol 1994;13:176.

13 Baer AN, Dessypries EN, Goldwasser E, Krantz SB. Blunted erythropoietin response to anaemia in rheumatoid Blunted erythropoietin response to anaem

14 Hochberg MC, Arnold CM, Hogans BB, Spivak JL. Serum immunoreactive erythropoietin in rheumatoid arthritis: impaired response to anemia. Arthritis Rheum 1988; 31:1318-21

15 Vreugdenhil G, Kontoghiorghes GJ, Van Eijk HG, Swaak AJG. Impaired erythropoietin responsivenes to the anemi in rheumatoid arthritis. A possible inverse relationship with iron stores and effects of the oral chelator 1,2-dimethyl-3-hydroxypyrid-4-one. Clin Exp Rheumato 1991;9:35-40

16 Jelkman W, Pagel H, Wolff M, Fandrey J. Monokines inhibit erythropoietin production in human hepatoma cultures and isolated perfused rat kidneys. Life Sci 1991;50:301-8.

17 Faquin WC, Schneider TJ, Goldberg MA. Effect of inflammatory cytokines on hypoxia-induced erythropoietin promatory cytokines on hypoxia-ind
duction. Blood $1992 ; 79: 1987-94$.

18 Means RT, Olsen NJ, Krantz ST, Dessypris EN, Graber SE, Stone WJ, et al. Treatment of the anemia of rheumatoid Stone WJ, et al. Treatment of the anemia of rheumatoid vivo studies. Arthritis Rheum 1989;32:638-42.
19 Takashina N, Kondo H, Kashiwazaki S. Suppressed serum erythropoietin response to anaemia and the efficacy of recombinant erythropoietin in the anaemia ofrheumatoid arthritis. $\mathcal{F}$ Rheumatol 1990;17:885-7.

20 Pincus T, Olsen NJ, Russel J, Wolfe F, Harris ER, Boccagno JA, et al. Multicenter study of recombinant human erythropoietin in correction of anemia in rheumatoid arthritis. Am ₹ Med 1990;89:161-8.

21 Salvarani C, Lasagni D, Casali B, Macchioni P, Boiardi I Rossi F, et al. Recombinant human erythropoietin therapy in patients with rheumatoid arthritis with the anemia of chronic disease. F Rheumatol 1991;18:1168-71.

22 Güdbjörnsson B, Hällgren R, Wide L, Birgegård G. Response of anaemia in rheumatoid erthritis to treatmen with subcutaneous recombinant human erythropoietin. Ann Rheum Dis 1992;51:747-52.

23 Pettersson T, Rosenlöf K, Friman C, Mickos A, Teppo A-M, Fyhrquist F. Succesful treatment of the anaemia of rheumatoid arthritis with subcutaneously administered recombinant human erythropietin. Scand 7 Rheumato recombinant hu

24 Murphy EA, Bell AL, Wojtulewski J, Brzeski M, Madhok R Capell HA. Study of erythropoietin in treatment of anaemia in patients with rheumatoid arthritis. BMf 1994 309:1337-8.

25 Vreugdenhil G, Manger B, Nieuwenhuizen C, Feelders RA Van Eijk HG, Swaak AJG. Iron stores and serum transferrin receptor levels during recombinant human erythropoietin treatment of anemia in rheumatoid arthritis. Ann Hematol 1992;65:265-8.

26 Eschbach JW. Erythropoietin 1991- an overview. Am f Kidney Dis 1991;18(suppl 1):3-9.

27 Swaak AJG, Nieuwenhuizen C, Vreugdenhil G. Recombinant human erythropoietin (r-hu-EPO) treatment in patients with rheumatoid arthritis and anaemia of chronic disease (ACD). Clin Exp Rheumatol 1995;12:577.

28 Arnett FC, Edworthy SM, Bloch DA, McShane DJ, Fries JF, Cooper NS, et al. The American Rheumatism Association 1987 revised criteria for the classification of rheumatoid arthritis. Arthritis Rheum 1988;31:315-24

29 Hochberg MC, Chang RW, Dwosh I, Lindsey S, Pincus T, Wolfe F. The Americam College of Rheumatology 1991 revised criteria for the classification of global functiona status in rheumatoid arthritis. Arthritis Rheum 1992 35:498-502.

30 Lundin P, Persson E, Weinfeld A. Comparison of hemosiderin estimation in bone marrow sections and bone marrow smears. Acta Med Scand 1964;175:383-90.

31 Paulus HE, Egger MJ, Ward JR, Williams HJ. Cooperative systemic studies of rheumatic diseases group. Analysis of improvement in individual rheumatoid arthritis patients treated with disease-modifying antirheumatic drugs, based on the findings in patients treated with placebo. Arthriti on the findings in patien
Rheum $1990 ; 33: 477-84$.

32 Felson DT, Anderson JJ, Boers M, Bombardier C, Chernoff $M$, Fried B, et al. The American College of Rheumatology preliminary core set of disease activity measures for rheumatoid arthritis clinical trials. Arthritis Rheum 1993, 36:729-40.

33 McConkey B. Clinical conundrum. $\mathrm{Br} f$ Rheumatol 1990;29:88.

34 Dixon JS, Bird HA, Sitton NG, Pickup ME, Wright V. C-reactive protein in the serial assessment of disease activity in rheumatoid arthritis. Scand $\mathcal{F}$ Rheumatol 1984;13:39 44

35 Kirwan JR. The Arthritis and Rheumatism Counci Low-dose Glucorticoid Study Group. The effect of glucocorticosteroids on joint destruction in rheumatoid arthritis. N Engl F Med 1995;333:142-6.

36 Kooistra MP, van Es A, Struyvenberg A, Marx JM. Iron metabolism in patients with the anaemia of end-stage renal disease during treatment with recombinant human erythropoietin. Br f Haematol 1991;79:634-9.

37 Muirden KD, Senator GB. Iron in the synovial membrane in rheumatoid arthritis and other joint diseases. Ann Rheum Dis 1968;27:38-48.

38 Biemond P, Swaak AJG, Van Eijk HG, Koster JF Intraarticular ferritin-bound iron in rheumatoid arthritis. Arthritis Rheum 1986;29:1187-93.

39 Blake DR, Gallagher PJ, Potter AR, Bell MJ, Bacon PA. The effect of synovial iron on the progression of rheumatoid disease. Arthritis Rheum 1984;27:495-501.

40 Nishiya K. Stimulation of human synovial cell DNA synthesis by iron. $¥$ Rheumatol 1994;21:1802-7.

41 Reddy PS, Lewis $M$. The adverse effects of intravenous iron dextran in rheumatoid arthritis. Arthritis Rheum 1969; 12:454-7.

42 Magaro M, Zoli A, Altomonte L, Mirone L, Corvino G Storti S. Iron chelation in rheumatoid arthritis: clinical
and laboratory evaluation. Ann Rheum Dis 1990;49:268-9.

43 Kimata H, Yoshida A, Ishioka C, Mikawa H. Effect of recombinant human erythropoietin on human IgE production in vitro. Clin Exp Immunol 1991;83:483-7.

44 Singh AB, Singh M, Palekar S, Levy S, Nunn C, Mann RA. The effects of recombinant human erythropoietin on the cell mediated immune response of renal failure patients. $f$ Med Clin Exp Theoret 1992;23:289-302. 